\title{
Alpha-2 Antiplasmin Measurement
}

National Cancer Institute

\section{Source}

National Cancer Institute. Alpha-2 Antiplasmin Measurement. NCI Thesaurus. Code C103351.

The determination of the amount of the alpha- 2 antiplasmin in a sample. 